\title{
Long-lived radionuclides in the environment: On the radioecology of lodine-129
}

\author{
R. Michel ${ }^{1}$, K. Klipsch ${ }^{1}$, Th. Ernst ${ }^{1}$, M. Gorny ${ }^{1}$, D. J akob ${ }^{1}$, J . Vahlbruch ${ }^{1}$, \\ H.-A. Synal ${ }^{2}$ and C. Schnabel ${ }^{3,4,5}$ \\ ${ }^{1}$ Zentrum für Strahlenschutz und Radioökologie (ZSR), Universität Hannover, Herrenhäuser \\ Str. 2, 30419 Hannover, Germany \\ ${ }^{2}$ Paul Scherrer Institut (PSI), c/o Institut für Teilchenphysik, ETH Hönggerberg, 8093 Zürich, \\ Switzerland \\ ${ }^{3}$ Institut für Teilchenphysik, ETH Hönggerberg, 8093 Zürich, Switzerland \\ ${ }^{4}$ Labor für Radio- und Umweltchemie, Universität Bern, Switzerland \\ ${ }^{5}$ Scottish Universities Environmental Research Centre, Scottish Enterprise Technology Park, \\ East Kilbride G75 OQF, UK
}

\begin{abstract}
The environmental abundances of ${ }^{129} \mathrm{I}$ and ${ }^{127} \mathrm{I}$ in Lower Saxony, Germany, and their pathways to animals and man were investigated. The iodine isotopes are in severe disequilibrium in the different environmental compartments. Today, the environmental isotope ratios range from $10^{-6}$ to $10^{-10}$. The highest ratios were found in North Sea water, the lowest in deep soil samples and ground water. A differentiation by about a factor of ten between the iodine isotopes was observed for different air-borne iodine species. Time series for iodine in precipitation show a decade-long increase of ${ }^{129}$ I fallout until the 1990ties and an ongoing constant input of ${ }^{129}$ I with deposition densities of $\sim 15 \mathrm{mBq} \mathrm{m}^{-2}$ per year. In surface waters, a dilution of the fall-out iodine takes place by stable iodine which is just weakly adsorbed in the soils. The isotope ratios in soils and ground waters demonstrate a high mobility and an accumulation of ${ }^{129} \mathrm{I}$ in the water unsaturated soil zones and an efficient migration into water saturated soil layers and ground water. The transfer into the food chain is ruled by the complex situation in the water-soil system. Given the environmental ${ }^{129}$ I abundances, the relatively low ${ }^{129} \mathrm{I} /{ }^{127}$ I ratios in human thyroid glands $\left(2 \cdot 10^{-9}-3 \cdot 10^{-8}\right)$ can only be explained by additional iodine sources with low ratios in the diet.
\end{abstract}

\section{INTRODUCTION}

Atmospheric nuclear weapons tests, nuclear accidents, and emissions from reprocessing plants have changed the natural abundances of the long-lived radionuclide ${ }^{129} \mathrm{I}\left(T_{1 / 2}=15.7 \mathrm{Ma}\right)$ in a sustainable manner. Mainly as a consequence of the ${ }^{129}$ I releases from the European reprocessing plants stable and radioactive iodine isotopes are in disequilibrium in all the abiotic and biotic environmental compartments in Western Europe. Iodine from precipitation is accumulated in soils, transported by surface water, infiltrating ground water and makes its way into the biosphere. But still today, the radioecology of ${ }^{129} \mathrm{I}$ is incompletely known [1]. Here, we present results of a project aimed at a comprehensive understanding of the abundances of ${ }^{129} \mathrm{I}$ and ${ }^{127} \mathrm{I}$ in Lower Saxony, Germany, and of their pathways through the different environmental compartments to man [1-7]. The project started with the development of reliable analytical protocols for the analysis of ${ }^{129} \mathrm{I}$ and ${ }^{127} \mathrm{I}$ via accelerator mass spectrometry (AMS), radiochemical neutron activation analysis (RNAA), ion chromatography (IC), and ICP-MS at all environmentally relevant concentrations and the establishment of a system of blank control and of general quality control and assurance [1-4]. 
Since the naturally occurring abundances of ${ }^{129}$ I are not accessible by RNAA, which for decades had been the only analytical technique to analyze ${ }^{129} \mathrm{I}$ in environmental materials, the natural equilibrium ${ }^{129} \mathrm{I} /{ }^{127} \mathrm{I}$ isotopic ratio could be assessed only recently via AMS. For the oceanic mixing layer, a natural ${ }^{129} \mathrm{I} /{ }^{127} \mathrm{I}$ ratio of about $1.5 \cdot 10^{-12}$ was measured $[8,9]$. Our investigations focused on the terrestrial biosphere and pedosphere $[4,5]$. We observed the so far lowest ${ }^{129} \mathrm{I} /{ }^{127} \mathrm{I}$ ratio in soils $(5.7 \pm 1.1) \cdot 10^{-12}$ in a sample from Lutovinovo (Russia) taken in 1939 [4]. However, the problem with pre-nuclear materials is that they are prone to contamination with man-made ${ }^{129}$ I during long storage times and consequently their analysis yields just upper limits of the pre-nuclear ratio. According to recent analyses [7] of iodine preparations, which had remained sealed since 1918 respectively 1935, the natural ${ }^{129} \mathrm{I} /{ }^{127} \mathrm{I}$ ratio in the terrestrial biosphere appears to be as low as $2.0 \cdot 10^{-13}$ with a geometric standard deviation of 1.4 .

After these initial methodological investigations, we studied the actual fallout situation in Lower Saxony by analyzing ${ }^{127} \mathrm{I}$ and ${ }^{129} \mathrm{I}$ in precipitation, surface, and ground waters [4]. The high ${ }^{129} \mathrm{I} /{ }^{127} \mathrm{I}$ ratios observed in precipitation could not be explained by the ratios reported at that time for the North Sea or the North Atlantic and the question remained open whether airborne or liquid releases from the European reprocessing plants were the main sources of ${ }^{129} \mathrm{I}$ in precipitation in Northern Germany or other European countries [4, 10]. Moreover, the ${ }^{129} \mathrm{I} /{ }^{127} \mathrm{I}$ ratios in surface and ground waters showed isotopic patterns distinctly different from those in precipitation [4] and demonstrated the necessity to investigate the entire pathways of iodine species through the environment. Here, we report results of this project dedicated to the measurement of radioecological parameters as exhibited by the long-term fallout of ${ }^{129}$ I in Northern Germany [11].

\section{EXPERIMENTAL}

The abundances of ${ }^{127} \mathrm{I}$ and ${ }^{129} \mathrm{I}$ were investigated in sea-water, air, precipitation, surface and ground waters, soils, plants, animals, foodstuffs, total diet, and human and animal thyroid glands. Detailed descriptions of the sampling procedures, sample preparations, analytical techniques (AMS, RNAA, ICP-MS and IC), and quality control measures are given elsewhere [1-4, 7, 11].

Since 1997, quarterly samples of precipitation and surface waters, and semiannual samples of ground water were collected from Lower Saxony, Germany, at various stations of the Deposition Measurement System. Moreover, surface and shallow ground water samples were taken at stations of the Information System of Surveillance of Environmental Radioactivity (IMIS). In order to establish a spatial separation, Lower Saxony was divided into four regions with respective sampling sites [4]. The four regions were chosen to represent the close proximity to the North Sea (region I), northern German lowlands distant from the North Sea (region II), the fringe of the Harz Mountains (region III), and an area of the Elbe River in Lower Saxony in the vicinity of Gorleben (region IV). In addition to open field precipitation sampled in each region, through-fall precipitation was collected quarterly in regions II and III; through-fall here means rain that falls down on forests and interacts with the canopy of the trees.

Nine samples of North Sea water were taken singularly near the German shore between June 1999 and June 2002 at Spieka-Neufeld, Neßmersiel, and Amrum. For air-borne iodine, the speciation as well as the particle size distribution of aerosols was investigated at the German coast of the North Sea at Föhr in April 2002 using a sampling unit which combined an 8-step Berner impactor with a system of selective filters collecting inorganic and organic iodine species with aerodynamic diameters $<1 \mu \mathrm{m}$. Seven deep soil profiles from regions II and III were investigated down to depths of $2.5 \mathrm{~m}$ in order to study the iodine migration [6]. Plants, animal products, and foodstuffs were sampled between 2001 and 2003 from regions I, III, and IV covering farmland as well as forests. For each material corresponding surface soil samples were collected to allow for the determination of transfer factors of the iodine isotopes into plants and animals. Samples of total diet were taken at the university restaurant of Hanover in 2002. Animal thyroid glands were obtained from region III in 2001 and 2002 and human ones from Hanover (region III) between 1998 and 2002 and from Hamburg (region I) in 2003. 


\section{RESULTS}

The samples of North Sea water showed geometric mean concentrations of $44 \times 1.6^{ \pm 1} \mathrm{ng} \mathrm{g}^{-1}$ for ${ }^{127} \mathrm{I}$ and $66 \times 1.7^{ \pm 1} \mathrm{fg} \mathrm{g}^{-1}$ for ${ }^{129} \mathrm{I}$. We use the convenient notation of e.g. $44 \cdot 1.6^{ \pm 1}$ to present geometric means, here 44, and geometric standard deviations, here 1.6. One femtogram (fg) of ${ }^{129} \mathrm{I}$ corresponds to $6.54 \mathrm{nBq}$. The corresponding geometric mean of the ${ }^{129} \mathrm{I} /{ }^{127} \mathrm{I}$ ratios was $1.5 \times 10^{-6}$ with a geometric standard deviation of 1.4. This value is four orders of magnitude higher than the ratio of $10^{-10}$ observed in oceanic mixing layer remote from ${ }^{129}$ I sources [12]. It is also much higher than the ratio of $4.6 \times 10^{-8}$ observed by Yiou et al. [12] in a sample of North Sea water taken in 1992. This increase is mainly attributed to increased liquid discharges from the European reprocessing plants, in particular from La Hague [5].

Table 1. Speciation of ${ }^{127} \mathrm{I}$ and ${ }^{129} \mathrm{I}$ in air as measured at Föhr in Northern Germany in June 2002 [7].

\begin{tabular}{|l|c|c|c|c|c|c|}
\hline & $\begin{array}{c}{ }^{127} \mathrm{I} \\
\text { in } \mathrm{ng} \mathrm{m}^{-3}\end{array}$ & $\begin{array}{c}{ }^{127} \mathrm{I} \\
\text { in \% }\end{array}$ & $\begin{array}{c}{ }^{129} \mathrm{I} \\
\mathrm{fg} \mathrm{m}^{-3}\end{array}$ & $\begin{array}{c}{ }^{129} \mathrm{I} \\
\mathrm{nBq} \mathrm{m}\end{array}$ & $\begin{array}{c}{ }^{129} \mathrm{I} \\
\text { in \% }\end{array}$ & $\begin{array}{c}{ }^{129} \mathrm{I}^{127} \mathrm{I} \\
\text { in } 10^{-7}\end{array}$ \\
\hline Bound to particles $>0,1 \mu \mathrm{m}$ & $1,9 \pm 0,4$ & 15 & $1,7 \pm 0,2$ & $11,1 \pm 1,3$ & 18 & $8,4 \pm 1,8$ \\
\hline Inorganic $<0,1 \mu \mathrm{m}$ & $5,8 \pm 0,9$ & 45 & $0,7 \pm 0,1$ & $4,6 \pm 0,7$ & 43 & $1,2 \pm 0,2$ \\
\hline Organic $<0,1 \mu \mathrm{m}$ & $5,1 \pm 0,8$ & 40 & $1,6 \pm 0,2$ & $10,5 \pm 1,3$ & 40 & $3,1 \pm 0,4$ \\
\hline Sum & $12,8 \pm 1,2$ & 100 & $4,0 \pm 0,3$ & $26,1 \pm 2,0$ & 100 & - \\
\hline
\end{tabular}

The ${ }^{129} \mathrm{I} /{ }^{127} \mathrm{I}$ ratios of iodine species in air (table 1 ) are significantly lower than in the coastal North Sea water. The particle size distribution at Föhr is dominated by sea spray; global aerosol is just of minor importance. This is also revealed by the ratios of the particle-bound iodine. Inorganic and organic iodine have lower, but differing ratios pointing to the complexity of their transfer from the sea into and through the atmosphere; see [7] for details.

In precipitation, the ${ }^{129} \mathrm{I} /{ }^{127} \mathrm{I}$ ratios are lower than in coastal areas of the North Sea (Fig. 1) except for region I close to the coast. As observed in an ice core from Switzerland [13], ${ }^{129} \mathrm{I} /{ }^{127} \mathrm{I}$ ratios in precipitation increased from the pre-nuclear equilibrium value to $10^{-9}$ between 1940 and 1950 in background regions of the northern hemisphere. In 1950, atmospheric ${ }^{129} \mathrm{I} /{ }^{127} \mathrm{I}$ ratios exceeded $10^{-9} .{ }^{129}$ I deposition in Western Europe does not show a prominent bomb peak as for instance observed for ${ }^{36} \mathrm{Cl}$ in the same ice core [14]. Ratios continued to increase until the end of the 1980s. Since then, ratios of nearly $10^{-6}$ were observed in Germany and Switzerland and remained constant until today. The fall-out of the Chernobyl accident was just a short-term episode with a highest measured ${ }^{129} \mathrm{I} /{ }^{127} \mathrm{I}$ ratio of nearly $10^{-5}$. Today, the North Sea appears as the dominant source of air-borne iodine in coastal regions of Northern Germany due to the liquid emissions of the European reprocessing plants. The ${ }^{129} \mathrm{I}$ deposition rates due to precipitation increased since 1950 from $0.01 \mathrm{mBq} \mathrm{m}^{-2} \mathrm{a}^{-1}$ by nearly three orders of magnitude and have leveled off after 1987. Iodine isotopes in open-field and through-fall precipitation yield different deposition rates, which are interpreted by us as being differently influenced by wet and wet-plus-dry fallout [4, 7, 11]. During the years 1997 - 2002, the mean annual ${ }^{129}$ I deposition rates in regions II ad III of Lower Saxony were $3.2 \mathrm{mBq} \mathrm{m}^{-2} \mathrm{a}^{-1}$ and $4 \mathrm{mBq} \mathrm{m}^{-2} \mathrm{a}^{-1}$, respectively, for wet deposition. Through-fall precipitation yielded mean annual ${ }^{129}$ I deposition rates in regions II ad III of $11 \mathrm{mBq} \mathrm{m}^{-2} \mathrm{a}^{-1}$ and $15 \mathrm{mBq} \mathrm{m}^{-2} \mathrm{a}^{-1}$, respectively. At the North Sea, the mean annual deposition rate via wet deposition was $12 \mathrm{mBq} \mathrm{m}^{-2} \mathrm{a}^{-1}$. The present ${ }^{129} \mathrm{I}$ deposition is inhomogeneous with time and location showing even some seasonal dependence [11]. 

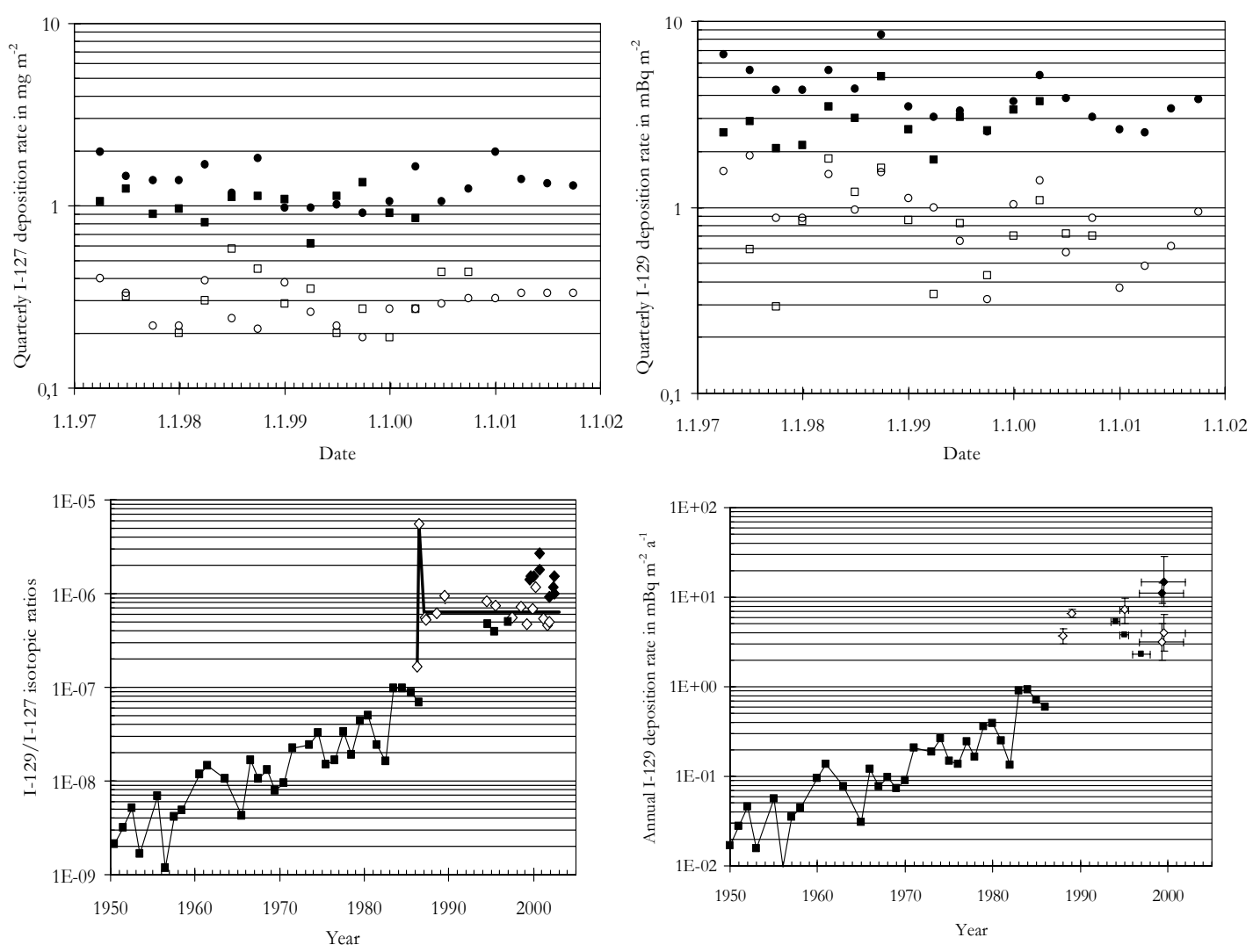

Figure 1. Time series of quarterly deposition rates of ${ }^{127} \mathrm{I}$ (top left) and ${ }^{129} \mathrm{I}$ (top right) in regions II and III both for open filed and through-fall precipitation (full symbols) and the development of ${ }^{129} \mathrm{I} /{ }^{127} \mathrm{I}$ ratios (bottom left) and of annual deposition rates of ${ }^{129} \mathrm{I}$ (bottom right) in Switzerland [10, 13] and Germany [4, 15-17] and this work.

The depth-dependence of iodine isotopes in seven soil profiles from Lower Saxony demonstrated the complexity of iodine migration [6]. Stable iodine in the soils originates from atmospheric input from the oceans. Considering the mean annual deposition rate of ${ }^{127} \mathrm{I}$ of $4.2 \times 1.2^{ \pm 1} \mathrm{mg} \mathrm{m}^{-2} \mathrm{a}^{-1}$ as derived from through-fall precipitation in regions II and III, the mean ${ }^{127} \mathrm{I}$ inventory of the seven soil profiles of $3.5 \times 1.6^{ \pm 1} \mathrm{~g} \mathrm{~m}^{-2}$ are the result of an input over thousands of years. Man-made ${ }^{129} \mathrm{I}$ in the soils was input during the last 50 years only. The ${ }^{129} \mathrm{I} /{ }^{127} \mathrm{I}$ ratios in the soil profiles vary by more than two orders of magnitude and show remarkable differences between the seven locations. But, the lowest ${ }^{129} \mathrm{I} /{ }^{127} \mathrm{I}$ ratios at deeper depths still are of the order of $10^{-10}$, i.e. about two orders of magnitude higher than the natural equilibrium ratio in the marine hydrosphere or the pre-nuclear ratio of $(5.7 \pm 1.1) \times 10^{-12}$ in the pre-nuclear soil from Lutovinovo, Russia [4]. Thus, man-made ${ }^{129} \mathrm{I}$ has already substantially migrated to deeper depths.

The migration of ${ }^{129} \mathrm{I}$ and ${ }^{127} \mathrm{I}$ in the soils can only be understood as a time-dependent kinetic process involving unspecific and specific adsorption processes and isotopic exchange depending strongly on the hydrological situation $[6,7]$. As a consequence of the long time which was available for the ${ }^{127}$ I to migrate into the ground, ${ }^{127}$ I could occupy more stable adsorption places with long characteristic exchange times. The sorption of ${ }^{129} \mathrm{I}$ in the soil layers mainly occurs by non-specific sorption and the need to exchange with ${ }^{127} \mathrm{I}$, which is adsorbed more strongly in deeper layers over long time scales, makes the recent ${ }^{129}$ I more mobile and more available than the large amount of ${ }^{127} \mathrm{I}$. It turns out that the migration of the iodine isotopes cannot be described by stationary equilibrium models but need time-dependent kinetic models which are not available so far. 
More than $99 \%$ of the ${ }^{129}$ I observed in the soils are located in the upper $60 \mathrm{~cm}$ of the profiles. This allows interpreting the ${ }^{129} \mathrm{I}$ inventories in the profiles as proxies for the total ${ }^{129} \mathrm{I}$ inventories. For the seven depth profiles from Lower Saxony, this yields a geometric mean of $168 \times 1.5^{ \pm 1} \mathrm{mBq} \mathrm{m}^{-2}$. This total inventory in Lower Saxony is more than three orders of magnitude higher than the pre-nuclear value derived for Lutovinovo, Russia, of $0.084 \pm 0,017 \mathrm{mBq} \mathrm{m}^{-2}$ [4]. The total inventory in Germany is also higher than in Moscow, Russia, or Zhitomir, Ukraine, both regions being not significantly contaminated by fall-out from the Chernobyl accident [5]. Only in areas of Ukraine seriously contaminated by this accident we observed higher total inventories than in Germany. There, ${ }^{129}$ I can be used for estimates of the fall-out of ${ }^{131} \mathrm{I}$ from the Chernobyl accident for the purpose of retrospective dosimetry [18].

As a consequence of the different input-histories of the two iodine isotopes, ${ }^{129} \mathrm{I}$ and ${ }^{127} \mathrm{I}$ are today in disequilibrium in all the investigated environmental compartments (Fig. 2). The measured ${ }^{129} \mathrm{I} /{ }^{127} \mathrm{I}$ ratios ranged from $2.7 \times 10^{-6}$ in coastal seawater from the North Sea to $1.0 \times 10^{-11}$ in ground water. Except for samples of thyroid glands, the concentrations of ${ }^{129}$ I were between $10^{-12} \mathrm{~g} \mathrm{~g} \mathrm{~g}^{-1}$ and $10^{-18} \mathrm{~g} \mathrm{~g}^{-1}$, i.e. $6.5 \mathrm{mBq} \mathrm{kg}^{-1}$ and $6.5 \mathrm{nBq} \mathrm{kg}^{-1}$. The concentrations of ${ }^{127} \mathrm{I}$ were found in the range from $10^{-5} \mathrm{~g} \mathrm{~g}^{-1}$ to $10^{-10} \mathrm{~g} \mathrm{~g}^{-1}$. Man-made ${ }^{129} \mathrm{I}$ was found at all depths sampled so far: in soils down to a depth of $2.5 \mathrm{~m}$ and in ground water to an infiltration depth of $10 \mathrm{~m}$.

The iodine isotopes precipitated from the atmosphere are introduced into the surface-water-soil system and fresh ${ }^{127} \mathrm{I}$ and ${ }^{129} \mathrm{I}$ exchange with the iodine isotopes already present in the soils. The ${ }^{127} \mathrm{I}$ concentrations in soils are strongly influenced by hydrological conditions. In surface soils, ${ }^{127} \mathrm{I}$ concentrations ranged from $2 \times 10^{-5} \mathrm{~g} \mathrm{~g}^{-1}$ to $5 \times 10^{-7} \mathrm{~g} \mathrm{~g}^{-1}$, those of ${ }^{129} \mathrm{I}$ were between $2.2 \times 10^{-13} \mathrm{~g} \mathrm{~g}^{-1}$ and $3 \times 10^{-14} \mathrm{~g} \mathrm{~g}^{-1}$, i.e. $1.1 \mathrm{mBq} \mathrm{kg}^{-1}$ and $0.2 \mathrm{mBq} \mathrm{kg}^{-1}$. The ${ }^{129} \mathrm{I}^{127} \mathrm{I}$ ratios in surface waters $\left(2.2 \times 10^{-6}\right.$ to $\left.1.7 \times 10^{-8}\right)$ and in surface soils $\left(2.1 \times 10^{-7}\right.$ to $\left.1.7 \times 10^{-9}\right)$ are lower than those in precipitation. In surface waters, a dilution of the fall-out iodine takes place with stable ${ }^{127} \mathrm{I}$ which is just weakly adsorbed in the soils and a considerable run-off of iodine must be taken into account. The ratios in soil profiles and ground waters demonstrate a high mobility and an accumulation of ${ }^{129} \mathrm{I}$ in the water unsaturated soil zones, an efficient migration into the water saturated soil layers and an ongoing transfer of man-made ${ }^{129} \mathrm{I}$ into ground water.

The ${ }^{129} \mathrm{I} /{ }^{127} \mathrm{I}$ ratios do not depend on the ${ }^{129} \mathrm{I}$ concentrations which are fairly uniform within a geometric standard deviation of $\sim 2$. Exceptions are forest soils with higher ${ }^{129}$ I concentrations. But, the ${ }^{129} \mathrm{I} /{ }^{127} \mathrm{I}$ ratios in surface soils are inversely proportional to the ${ }^{127} \mathrm{I}$ concentrations. In the soil samples, the highest ${ }^{129} \mathrm{I}$ concentrations went up to $6.4 \times 10^{-13} \mathrm{~g} \mathrm{~g}^{-1}$, i.e. $4.2 \mathrm{mBq} \mathrm{kg}$, and ${ }^{129} \mathrm{I}^{127} \mathrm{I}$ ratios up to $4.8 \times 10^{-7}$ in forest soils. ${ }^{129} \mathrm{I}$ and ${ }^{127} \mathrm{I}$ concentrations in vegetation and foodstuff and the transfer factors for ${ }^{129} \mathrm{I}$ and ${ }^{127} \mathrm{I}$ show influences of various effects. For grass, cereals and leafy vegetables elevated ${ }^{129} \mathrm{I} /{ }^{127} \mathrm{I}$ ratios point to the direct contamination by wet and dry deposition. For other vegetables, milk, meat, and mushrooms the root uptake is clearly seen; for equal ${ }^{129} \mathrm{I} /{ }^{127} \mathrm{I}$ ratios their ${ }^{129} \mathrm{I}$ and ${ }^{127} \mathrm{I}$ concentrations are in-between those of soils and surface water. As long as the transfer of iodine isotopes to plants is dominated by root transfer the respective ${ }^{129} \mathrm{I} /{ }^{127} \mathrm{I}$ ratios and ${ }^{127} \mathrm{I}$ respectively ${ }^{129} \mathrm{I}$ concentrations plot into the regions indicted in Fig. 2 spread out by the data for sea water, precipitation, surface water and surface soils. Only if direct contamination of plant surfaces due to fallout is relevant the respective data plot outside these regions. This is e.g. the case for grass, grains, or leafy vegetables from region I as a consequence of direct contamination by sea spray. The behaviour of iodine isotopes in surface soils rules also their transfer to animals (Fig. 3). In the plot of ${ }^{129} \mathrm{I} /{ }^{127} \mathrm{I}$ versus ${ }^{127} \mathrm{I}$ concentrations an inverse correlation is observed for the milk data parallel to that in the soils.

For the transfer of iodine isotopes to humans the analyses of total diet turned out to be particularly important. In nine out of ten samples no ${ }^{129} \mathrm{I}$ was detectable with detection limits between $0.55 \mathrm{fg} \mathrm{g}^{-1}$ and $1.4 \mathrm{fg} \mathrm{g}^{-1}$, equivalent to $4.3 \mathrm{nBq} \mathrm{g}^{-1}$ und $9.3 \mathrm{nBq} \mathrm{g}$. The ${ }^{129} \mathrm{I}^{127} \mathrm{I}$ ratios in these samples were well below $10^{-8}$. Only in one sample of total diet contained fish ${ }^{129}$ I was detectable and showed a ${ }^{129} \mathrm{I} /{ }^{127} \mathrm{I}$ ratio of $10^{-7}$. Since there were relatively high ${ }^{127} \mathrm{I}$ concentrations $\left(0.1 \mu \mathrm{g} \mathrm{g}^{-1}-0.2 \mu \mathrm{g} \mathrm{g}^{-1}\right)$ in the diet, we assume that most of the original iodine isotopes in the food were lost during cooking and that iodinated salt with low ${ }^{129} \mathrm{I} /{ }^{127} \mathrm{I}$ ratios was added later. The iodine concentrations in the total diet were equivalent to daily ${ }^{127}$ I intakes between $180-400 \mu \mathrm{g} \mathrm{d}^{-1}$, more than the value $150 \mu \mathrm{g} \mathrm{d}^{-1}$ recommended by WHO. Thus, it appears that there are additional source of iodine in the diet which might be decoupled from the normal radioecological pathways. Respective analyses are underway to confirm this assumption. 

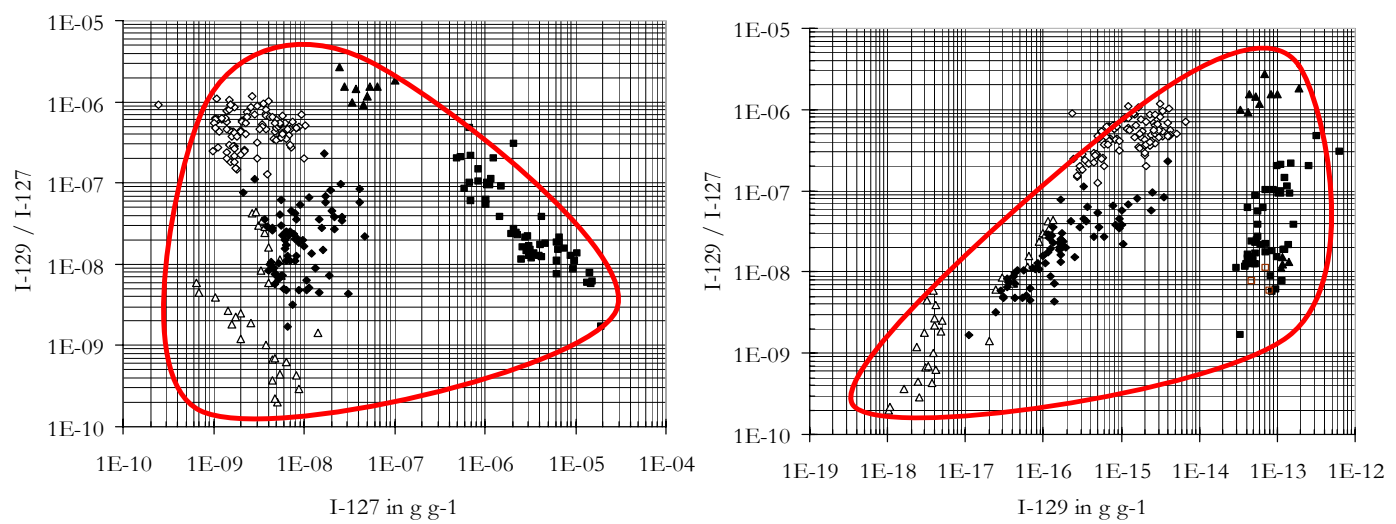

Figure 2. ${ }^{129} \mathrm{I} /{ }^{127} \mathrm{I}$ ratios versus ${ }^{127} \mathrm{I}$ (left) and ${ }^{129} \mathrm{I}$ (right) concentrations in the water-soil system in Lower Saxony, Germany (North Sea water: full triangles, precipitation: open diamonds, surface water: full diamonds, ground water: open triangles, soil: full squares).
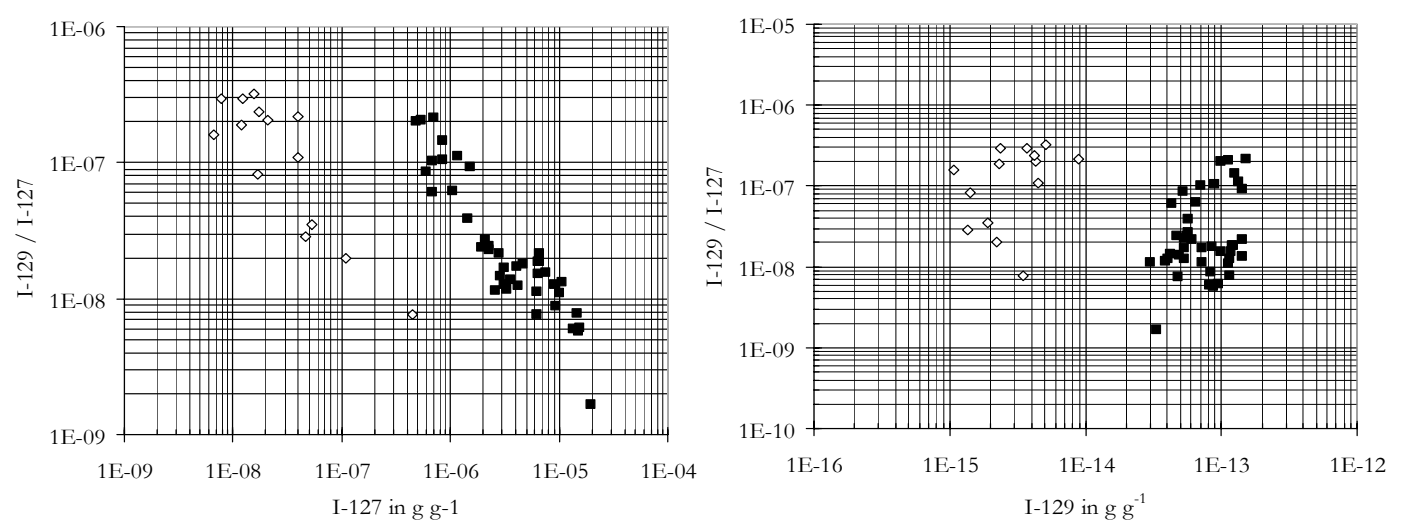

Figure 3. ${ }^{129} \mathrm{I} /{ }^{127} \mathrm{I}$ ratios versus ${ }^{127} \mathrm{I}$ (left) and ${ }^{129} \mathrm{I}$ (right) concentrations in milk (open diamonds) and surface soils (full squares) in Lower Saxony, Germany.
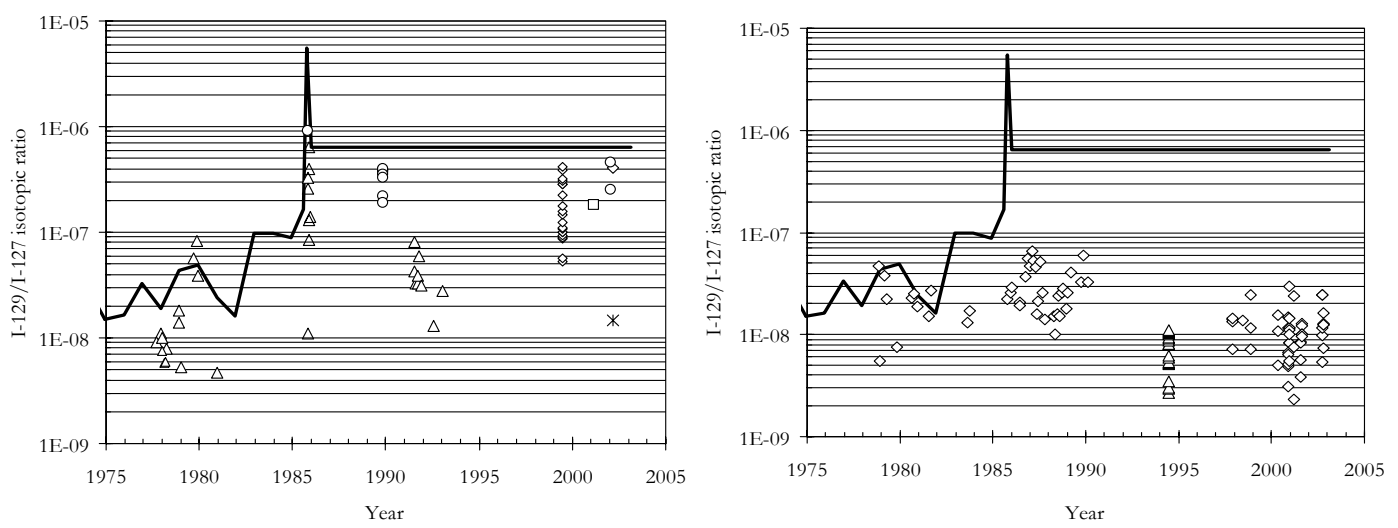

Figure 4. ${ }^{129} \mathrm{I} /{ }^{127} \mathrm{I}$ ratios in animal (left) and human (right) thyroid glands from Europe remote from ${ }^{129} \mathrm{I}$ sources; see [11] for details and references. The solid line is an eye-guide only, representing the development of ${ }^{129} \mathrm{I} /{ }^{127} \mathrm{I}$ ratios in precipitation. 
In Fig. 4 we present all ${ }^{129} \mathrm{I} /{ }^{127} \mathrm{I}$ ratios in animal and human thyroid glands reported in Europe so far for areas remote from nuclear installations. Since the 19790s such measurements were made by Handl and coworkers; [19-21] and references therein. Recently, data for sheep from Denmark and for humans from Belarus were reported by Hou et al. [22]. In animal thyroid glands the ${ }^{129} \mathrm{I} /{ }^{127} \mathrm{I}$ ratios closely respond to ratios in precipitation. The ${ }^{129} \mathrm{I} /{ }^{127} \mathrm{I}$ ratios in human thyroid glands are lower than other biospheric ratios. This can be explained partially that those foodstuffs with the highest ${ }^{127} \mathrm{I}$ contents show the lowest ${ }^{129} \mathrm{I} /{ }^{127} \mathrm{I}$ ratios because of the dilution with stable iodine from the soils. Thyroid glands from cows and sheep exhibit ${ }^{129} \mathrm{I} /{ }^{127} \mathrm{I}$ ratios which are higher by an order of magnitude than those of humans and reveal the ongoing influence of wet and dry deposition onto the pastures. ${ }^{129} \mathrm{I} /{ }^{127} \mathrm{I}$ ratios exceeding $10^{-6}$ were observed so far only reported for the Nord Cotentin under the direct influence of the La Hague emissions [23]. Human thyroid glands in Germany show lower ${ }^{129} \mathrm{I} /{ }^{127} \mathrm{I}$ ratios than animal thyroid glands and, moreover, the ratios $\left(2 \times 10^{-9}-3 \times 10^{-8}\right)$ of human thyroid glands sampled between 1998 and 2002 in Lower Saxony are lower than those investigated between 1985 and $1990 .{ }^{129} \mathrm{I} /{ }^{127} \mathrm{I}$ ratios in thyroid glands from Belarus [22] are even lower than those from Lower Saxony.

The average ${ }^{129} \mathrm{I} /{ }^{127} \mathrm{I}$ ratios of $1.1 \times 10^{-8}$ in human thyroid glands are equivalent to an annual equivalent dose to the thyroid of $\sim 6 \mathrm{nSv}$ for adults. In spite of the fact that the present global biospheric ${ }^{129}$ I abundances do not give rise to significant radiation exposures, the future development should be carefully surveyed. The disequilibria between the iodine isotopes observed in Europe offer a unique chance to use ${ }^{129} \mathrm{I}$ as a man-made radiotracer for the pathways of iodine through the environment.

\section{Acknowledgements}

The authors thank W. Städe and J. Döhring (Niedersächsischen Landesamt für Ökologie) for supplying the samples of precipitation, surface and ground water and H.D. Tröger and K. Albrecht (Institut für Rechtsmedizin, Medizinische Hochschule Hannover) and K. Püschel (Institut für Rechtsmedizin des Universitätsklinikums Hamburg-Eppendorf) for samples of human thyroid glands. The irradiations were performed at the research reactor of the GKSS Forschungszentrums Geesthacht GmbH. We thank C. Vogt (Institut für Anorganische Chemie der Universität Hannover) for the opportunity to perform the ICP-MS measurements. This work was funded by the Deutsche Forschungsgemeinschaft and the Bundesministerium für Umwelt, Naturschutz und Reaktorsicherheit.

\section{References}

[1] A. Schmidt, Ch. Schnabel, J. Handl, D. Jakob, R. Michel, H.-A. Synal, J.M. Lopez, M. Suter, Sci. Total Envionm. 223, 131 (1998).

[2] S. Szidat, A. Schmidt, J. Handl, D. Jakob, R. Michel, H.-A. Synal, M. Suter, J. Radioanal. Chem. 244, 45 (2000).

[3] S. Szidat, A. Schmidt, J. Handl, D. Jakob, R. Michel , H.-A. Synal, Ch. Schnabel, M. Suter, J.M. Lopez-Gutierrez, Kerntechnik 65, 160 (2000).

[4] S. Szidat, A. Schmidt, J. Handl, D. Jakob, W. Botsch, R. Michel, H.-A. Synal, C. Schnabel, M. Suter, J.M. López-Gutiérrez, W. Städe, Nucl. Instr. Meth. Phys. Res. B172, 699 (2000).

[5] R. Michel, T. Ernst, D. Jakob, S. Szidat, H.-A. Synal, Ch. Schnabel, in Proceedings EUROSAFE, Berlin 2002, November 4-5, http://www.eurosafe-forum.org/grs/de/index.htm (2002).

[6] T. Ernst, S. Szidat, J. Handl, D. Jakob, R. Michel, Ch. Schnabel, H.-A. Synal, F.J. Santos Arevalo, I. Benne, J. Boess, E. Gehrt, A. Capelle, J. Schneider, W. Schäfer, J. Böttcher, Kerntechnik 68, 155 (2003).

[7] T. Ernst, Anthropogenes Iod-129 als Tracer für Umweltprozesse - Ein Beitrag zum Verhalten von Spurenstoffen bei der Migration in Böden und beim atmosphärischen Transport. Ph.D. thesis, University Hanover (2003) http://edok01.tib.uni-hannover.de/edoks/ e01dh04/.pdf.

[8] D.R. Schink, P.H. Santschi, O. Corapcioglu, P. Sharma, U. Fehn, Earth Planetary Sci. Letters 135, 131 (1995).

[9] J.E. Moran, U. Fehn, R.T.D. Teng, Chemical Geology 152, 193 (1998). 
[10] Ch. Schnabel, J.M. López-Gutiérrez, S. Szidat, M. Sprenger, H. Wernli, J. Beer, H.A. Synal, Radiochimica Acta 89, 815 (2001).

[11] R. Michel, K. Klipsch, Th. Ernst, M. Gorny, D. Jakob, J. Vahlbruch, H.-A. Synal, C. Schnabel, Ableitung von radioökologischen Parametern aus dem langfristigen Eintrag von Iod-129 (in German) Abschlussbericht zum Forschungsvorhaben StSch 4285, August 2004, www.zsr.uni-hannover.de

[12] F. Yiou, G.M. Raisbeck, Z.Q. Zhou, L.R. Kilius, Nucl. Instr. Meth. Phys. Res. B92, 436 (1994).

[13] M.J.M. Wagner, B. Dittrich-Hannen, H.-A. Synal, M. Suter, U. Schotterer, Nucl. Instr. Meth. Phys. Res. B113, 490 (1996).

[14] H.-A. Synal, J. Beer, G. Bonani, M. Suter, W. Wölfli, Nucl. Instr. Meth. Phys. Res. B52, 483 (1990).

[15] M. Paul, D. Fink, G. Hollos, S.A. Kaufman, W. Kutschera, M. Magaritz, Nucl. Instr. Meth. Phys. Res. B29, 341 (1987).

[16] H. Bachhuber, K. Bunzl, J. Environ. Radioactivity 16, 77 (1992).

[17] G. Krupp, D.C. Aumann, J. Environ. Radioactivity 46, 287 (1999).

[18] R. Michel, J. Handl, Th. Ernst, W. Botsch, S. Szidat, A. Schmidt, D. Jakob, D. Beltz, L.D. Romantschuk, H.-A. Synal, C. Schnabel, J.M. López-Gutiérrez, Sci. Total Environm. (2004) in press.

[19] J. Handl, E. Oliver, D. Jakob, K.J. Johanson, P. Schuller, Health Phys. 65, 265 (1993).

[20] J. Handl, Radiochimica Acta 72, 33 (1996).

[21] L. vanMiddlesworth, J. Handl, Health Physics 73, 647 (1997).

[22] X.L. Hou, A.F. Melencheko, J. Kucera, H. Dahlgaard, S.P. Nielsen, Sci. Total Environm. 302, 63 (2003).

[23] C. Fréchou, D. Calmet, X. Bertho, A. Gaudry, Science Total Environm. 293, 59 (2002). 